follow-up duration, RF levels, number of cycles received, DAS28(CRP) at baseline and IgG or IgM levels at baseline. SPSS software 21.0 and GraphPad Prism 5.00 were used for statistical analyses.

Results: 76 patients were included followed up for a median (range) of 48 (6-135) months. 65 were female $(84.4 \%)$ with a mean \pm SD age of $63.5 \pm 11.8$ and baseline DAS28(CRP) of $5.98 \pm 1.25 .67 .8 \%$ and $65.2 \%$ of patients were RF positive, respectively (Table). At baseline, none of them had low lgG or IgA levels while 4 patients had lgM levels below $40 \mathrm{mg} / \mathrm{ml}$. The patients received median (range) 8 (2-20) cycles of RTX. In total, $43.4 \%, 25 \%$, $28.9 \%$ and $5.3 \%$ developed HGG, low $\operatorname{lgG}$, $\lg M$ and $\lg A$, respectively. In $15.8 \%$ of the patients, at least 2 immunoglobulins subclasses were low. Levels of $\lg G$ and $\operatorname{lgM}$, at the last visit, were negatively correlated with the number of RTX cycles received (IgG: $\mathrm{p}=0.02, \mathrm{r}=-0.27$; $\operatorname{lgM}: \mathrm{p}=0.03, \mathrm{r}=-0.25$ ). At baseline, no differences were recorded between patients that developed HGG and those who did not (Table). Patients who developed low lgG or IgM had lower baseline levels of IgG or IgM levels, respectively (Table). Multivariable analyses revealed number of cycles received $(p=0.03)$ and baseline IgM levels $(p=0.03)$ as predictors of "low lgM" occurrence, while no variable was identified for "low IgG". At the end of follow up, the patients who developed HGG or low IgM compared to those who did not, exhibited lower DAS28 (Table). Concurrent treatment, during follow up or at the time of the last visit did not differ between the various groups, except from co-administration of methotrexate, which was more frequent at the time of last visit in patients who did not develop HGG $(43.5 \%$ Vs $30.3 \%, p=0.04)$. No difference was observed in infections rate, among all analyses performed.

Table 1.

\begin{tabular}{|c|c|c|c|}
\hline characteristic & $\begin{array}{c}\text { Not developed } \\
\text { Hypogammaglobulinemia }\end{array}$ & $\begin{array}{c}\text { Developed } \\
\text { Hypogammaglobulinemia } \\
\end{array}$ & peralue \\
\hline \multicolumn{4}{|c|}{ Basseline characteristics } \\
\hline 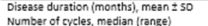 & $44.6 \pm 23.1$ & $55.9 \pm 30.7$ & $\begin{array}{l}0.125 \\
0.157\end{array}$ \\
\hline 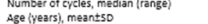 & $\begin{array}{c}8(2.20) \\
61.5 \pm 12.2\end{array}$ & $\begin{array}{c}8(2-15) \\
662+110\end{array}$ & $\begin{array}{l}0.157 \\
0.055\end{array}$ \\
\hline 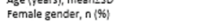 & $\begin{array}{l}61.5 \div 12.2 \\
37 / 43(86.1)\end{array}$ & $28 / 33(849 ;$ & $\begin{array}{l}0.005 \\
1000\end{array}$ \\
\hline 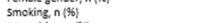 & $7 / 13(53.8)$ & $3 / 10(30.0)$ & 0.402 \\
\hline & $20 / 31$ 165.5) & $18 / 24(75.0 \%$ & \\
\hline \multicolumn{4}{|l|}{ DAs28 (baseline), meantso } \\
\hline \multirow{3}{*}{ 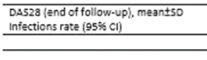 } & $4.16 \pm 1.36$ & $3.12 \pm 1.32$ & \\
\hline & 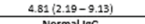 & $1.62(0.33-4.75)$ & 0.09 \\
\hline & \multicolumn{3}{|c|}{$\begin{array}{c}\text { Normal IgG } \\
\text { Baseline characteristics } \\
\end{array}$} \\
\hline Disesse duration (months), menn \pm so & $46.0 \pm 23.1$ & $60.2 \pm 35.4$ & \\
\hline Number of cyles, median (rrange) & $8(2-15)$ & $\begin{array}{l}00.2-2354 \\
9(2-20)\end{array}$ & 0.157 \\
\hline Age (years), meantso & $62.2 \pm 12.4$ & $67.7 \pm 9.0$ & 0.169 \\
\hline 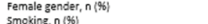 & $47 / 57(82.5)$ & $18 / 19(94.7)$ & $\begin{array}{l}0.273 \\
0.179\end{array}$ \\
\hline 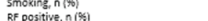 & 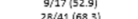 & & \\
\hline & 28/41 (68.3) & $10 / 144(77.4)$ & 1.000 \\
\hline \multirow{2}{*}{\multicolumn{4}{|c|}{$\begin{array}{l}\text { DAS23 (bsseline), mean } \leq D \\
\text { Do }\end{array}$}} \\
\hline & & & \\
\hline 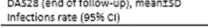 & $\begin{array}{l}3.87 \pm 1.12 \\
.88(1.86-7.14)\end{array}$ & $\begin{array}{c}3.27+1.39 \\
7.550 .020-631\end{array}$ & $\begin{array}{l}0.166 \\
0.312\end{array}$ \\
\hline \multirow{2}{*}{\multicolumn{4}{|c|}{$\begin{array}{l}\text { Normal IgM } \\
\text { Baseline characteristics }\end{array}$}} \\
\hline & & & \\
\hline Disease duration (months), mean \pm SO & $48.1 \pm 28.2$ & $53.1 \pm 24.6$ & 0.314 \\
\hline & & & \\
\hline 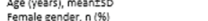 & $61.8 \pm 12.1$ & $67.8 \pm 10.1$ & 0.06 \\
\hline 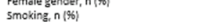 & $7 / 17(41.2)$ & $\begin{array}{c}18,23(738.3) \\
3 / 6(50.0)\end{array}$ & $\begin{array}{l}0.2191 \\
1.000\end{array}$ \\
\hline RF positive, $n$ (\%) & $26 / 39(66.7)$ & & \\
\hline \multirow{3}{*}{\multicolumn{4}{|c|}{ 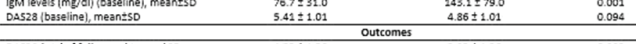 }} \\
\hline & & & \\
\hline & & & \\
\hline 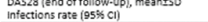 & $\begin{array}{l}4.03 \pm 1.38 \\
3.53(1.61-6.70)\end{array}$ & $\begin{array}{c}2.92+1.26 \\
2.57(052-7.51)\end{array}$ & $\begin{array}{l}0.003 \\
0.671\end{array}$ \\
\hline
\end{tabular}

Conclusion: HGG following RTX can be developed in about $40 \%$ of RA patients even after several treatment cycles. It is related to baseline immunoglobulin levels and possibly combined with better disease outcomes. The latter is observed primarily with $\operatorname{lgM}$. No increased risk of major infections was identified.

Disclosure of Interests: None declared

DOI: 10.1136/annrheumdis-2019-eular.7245

\section{AB0376 RESULTS OF A MANDATORY SWITCHING FROM ORIGINATOR TO BIOSIMILAR ETANERCEPT IN 117 PATIENTS WITH INFLAMMATORY ARTHRITIS FROM A SINGLE CENTER}

Sabela Fernández, Senen Gonzalez, Carmen Ordas-Calvo, Edilia GarcíaFernández, Belén Rodríguez-De-Castro, Jesús Babío. Gijón, Rheumatology, Gijón, Spain

Background: Currently available evidence indicates that a single switch from a bio-originator to one of its biosimilars is safe and effective and has cost benefits to the National Health Systems. However, there is some reluctance to switch patients due to lack of real-world data and differences between patients treated in the setting of real clinical practice and those of clinical trials

Objectives: We aimed to investigate the efficacy and safety of Etanercept-biosimilar (SB4), in a non-medical switch in patients with inflammatory arthritis (IA)
Methods: At Cabueñes Hospital a non-medical switch from Etanercept (ETN) to SB4 was carried out in March 2018. Inflammatory arthritis patients (rheumatoid arthritis (AR), psoriatic arthritis (APS), axial spondyloarthritis (AS), juvenile idiopathic arthritis (JIA)) were included in this single-center retrospective observational study from March 2018 to December 2018. Reasons for SB4 withdrawal were categorized as lack of effect (LOE), adverse events (AE) or others.

Results: A total of 117 patients were identified, $100 \%$ were switched to SB4 maintaining the same dose. Disease duration was $5(2-8,5)$ years. 49 patients $(41 \%)$ had basal optimized dose of ETN (dose down-titration or dose interval expansion). In most patients ETN was the first biologic. 31 patients $(26 \%)$ stopped SB4 treatment during follow-up, mainly due to LOE $(67 \%)$ or AE $(25 \%)$, with median duration of SB4 3,5 months (1,95,9 ). Most $A E$ that led to withdrawal were dermatological (injection-site reactions, skin rash). 11 patients switched back to ETN, 15 to others. Two patients died, both were APS (one sudden death and one aneurysmal subarachnoid hemorrhage). After switching to SB4, one stable patien with AS had recurrent acute anterior uveitis, and psoriasis worsening were noted in 2 patients with APS. 2 patients needed reinstatement of the full dose of biologic because of LOE. The clinical situation on ETN was stable in 23 of the 31 (74\%) patients who stopped SB4 (no flares or changes in treatment in the last 6 months before switch).

Table 1 summarizes baseline characteristics and treatment outcomes. Conclusion: Biosimilar switch of SB4 was successful in over $74 \%$ of cases and was well tolerated.

Most patients who stopped SB4 due to LOE had a clinical stable situation in this observational study. Some concerns regarding the safety profile and interchangeability have raised and further evidence on the efficacy of transitioning from reference ETN is needed.

\section{REFERENCES}

[1] Kay J, Schoels MM, Dörner T, et al. Ann Rheum Dis 2018;77:165-174

[2] Emery P, Vencovsky J, Sylwestrzak A, et al. Ann Rheum Dis 2017;76:5157

[3] Glintborg B, et al. Ann Rheum Dis 2019 Feb;78(2):192-200

Table 1:

\begin{tabular}{|c|c|c|c|c|}
\hline & RA $(n=47)$ & $\begin{array}{c}\text { APS } \\
(n=29)\end{array}$ & AS $(n=30)$ & JIA $(n=8)$ \\
\hline Age (years) & $62(53-71)$ & $51(46-60)$ & $49(42-60)$ & $\begin{array}{l}42(30- \\
51)\end{array}$ \\
\hline Female, n (\%) & $33(70,2 \%)$ & $11(37,9 \%)$ & $4(13,3 \%)$ & $2(25 \%)$ \\
\hline Monotherapy, n (\%) & $17(36 \%)$ & $16(55 \%)$ & $30(100 \%)$ & $6(75 \%)$ \\
\hline Dose optimization, n (\%) & $18(38,6 \%)$ & $13(44,8 \%)$ & $12(40 \%)$ & $5(62,5 \%)$ \\
\hline Duration of ETN (years, median IQR) & $4(1,8-6)$ & $4,2(2-6)$ & $5,9(2-10,6)$ & $\begin{array}{c}6(4,1- \\
8,2)\end{array}$ \\
\hline $\begin{array}{l}\text { Other biologic drug prior to ETN, } n \\
(\%)\end{array}$ & $6(12,7 \%)$ & $7(24,1 \%)$ & $6(20 \%)$ & $1(12,5 \%)$ \\
\hline \multicolumn{5}{|l|}{ 9-month treatment outcomes } \\
\hline Withdrawal during follow-up, n (\%) & $15(31,9 \%)$ & $8(27.5 \%)$ & $6(20 \%)$ & $1(12,5 \%)$ \\
\hline $\begin{array}{l}\text { Duration of SB4 (months, median } \\
\text { IQR) }\end{array}$ & $\begin{array}{c}3,8(1,9- \\
5,1)\end{array}$ & $4,3(2-6,1)$ & $\begin{array}{l}2,3(1,4- \\
5,6)\end{array}$ & 5,9 \\
\hline
\end{tabular}

Disclosure of Interests: None declared

DOI: 10.1136/annrheumdis-2019-eular.7739

\section{AB0377 CLINICAL SIMILARITY OF ABP 710 WITH INFLIXIMAB (REFERENCE PRODUCT) IN SUBJECTS WITH MODERATE TO SEVERE RHEUMATOID ARTHRITIS}

Mark C. Genovese ${ }^{1}$, Juan Sanchez-Burson ${ }^{2}$, Myungshin Oh ${ }^{3}$, Éva Balázs ${ }^{4}$, Jeffrey Neal ${ }^{5}$, Gary Fanjiang ${ }^{6}$, Stanley Cohen ${ }^{7}{ }^{1}$ Stanford, Division of Immunology and Rheumatology, Palo Alto, United States of America; ${ }^{2}$ Hospital Infanta Luisa, Sevilla, Spain; ${ }^{3}$ Amgen, Thousand Oaks, United States of America; ${ }^{4}$ Csongrád Megyei Dr. Bugyi István Kórház, Sima Ferenc, Hungary; ${ }^{5}$ Bluegrass Community Research, Lexington, $K Y$, United States of America; ${ }^{6}$ Amgen, Thousand Oaks, CA, United States of America; ${ }^{7}$ Metroplex Clinical Research, Dallas, Tx, United States of America

Background: $A B P 710$ is being developed as a biosimilar to infliximab. Both ABP 710 and infliximab reference product (RP) inhibit tumor necrosis factor-alpha and have been shown to be structurally and functionally similar in analytical assessments. In a phase 1 clinical pharmacokinetic (PK) study both were shown to be bioequivalent for PK 